\title{
Deciphering interfungal relationships in the 410-million-yr-old Rhynie chert: Sporocarp formation in glomeromycotan spores *
}

Michael Krings ${ }^{\mathrm{a}, \mathrm{b}, *}$, Thomas N. Taylor ${ }^{\mathrm{b}}$, Hans Kerp ${ }^{\mathrm{c}}$, Christopher Walker ${ }^{\mathrm{d}, \mathrm{e}}$

${ }^{a}$ Department für Geo- und Umweltwissenschaften, Paläontologie und Geobiologie, LudwigMaximilians-Universität, and Bayerische Staatssammlung für Paläontologie und Geologie, Richard-Wagner-Straße 10, 80333 Munich, Germany

${ }^{\mathrm{b}}$ Department of Ecology and Evolutionary Biology, and Natural History Museum and Biodiversity Institute, University of Kansas, Lawrence, KS 66045-7534, USA

${ }^{\mathrm{c}}$ Forschungsstelle für Paläobotanik am Geologisch-Paläontologischen Institut, Westfälische Wilhelms-Universität Münster, Heisenbergstraße 2, 48149 Münster, Germany

${ }^{\mathrm{d}}$ Royal Botanic Garden Edinburgh, 21A Inverleith Row, Edinburgh EH3 5LR, UK

${ }^{\mathrm{e}}$ School of Earth Sciences and Environment, University of Western Australia, 35 Stirling Highway, Crawley, WA 6009, Australia

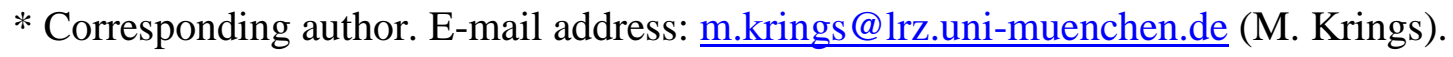

\ Corresponding editor: Marc Philippe.

\begin{abstract}
Fungi today enter into relationships with other fungi in many ways. Although this was likely also the case in the geologic past, detailed descriptions of interfungal associations and interactions based on fossils remain scarce. Sporocarps bounded by a peridium-like envelope occur singly within the lumen of large glomeromycotan spores (Palaeomyces gordonii var. major) from the Lower Devonian Rhynie chert. The envelope consists of multi-branched, interlacing hyphae. At the tips of hyphae, extending from the envelope into the lumen are produced spheroidal to urn-shaped spores. Similar sporocarps are found in several present day species in the Glomeraceae. Clusters of spores, superficially resembling sporocarps, may also
\end{abstract}


form within dead spores from any member of the Glomeromycota, including non-sporocarpic groups such as Ambispora, Acaulospora, and the Gigasporaceae, probably because they provide a shielded or otherwise advantageous environment for sporulation. The sporocarps in P. gordonii var. major from the Rhynie chert provide important information for reconstructing the numerous levels of fungal associations and interactions that existed in early continental ecosystems.

Keywords:

Early Devonian

Fossil fungi

Glomeraceae

Mycorrhizal fungi

Palaeomyces

Sporulation

\section{Introduction}

One of the major contributions to our understanding of early terrestrial ecosystems was a series of papers on structurally preserved land plants and microorganisms from the Lower Devonian Rhynie chert in Aberdeenshire, Scotland (Kidston and Lang, 1917, 1920a, b, 1921a, b). Since the initial descriptions there have been numerous contributions that have provided additional details about the land plants, and others that have greatly expanded our knowledge of the organisms (e.g., animals, fungi, algae, cyanobacteria) that co-occur with the land plants in the Rhynie chert. Still other studies have focused on associations and interactions that existed between different organisms in the Rhynie paleoecosystem. One of the most frequently encountered associations in the Rhynie chert is the colonization of fungal spores by various types of other fungi (Taylor et al., 2003). Kidston and Lang (1921b) illustrate several examples of such intrusive fungi in the form of reproductive units of various sizes that occur in the lumen of the host spores. Other fungal spores in the Rhynie chert contain tenuous mycelia with terminal reproductive units (Krings et al., 2009, 2010). Still other Rhynie chert fungi developed on the surface or between individual layers of the wall of fungal spores (Taylor et al., 1992; Hass et al., 1994; Krings and Taylor, 2014). Nevertheless, only a few of these intricate interfungal relationships have been described and evaluated in detail. 
In this paper we revisit one of the interfungal relationships from the Rhynie chert initially reported by Kidston and Lang (1921b). We based our study on new specimens that are better preserved than the material used in the original description, and thus permit a more complete assessment and photographic documentation of details. The association consists of large glomeromycotan spores containing sporocarps or clusters of spores and mycelium formed by another fungus. The sporocarps are bounded by a peridium-like hyphal envelope and produce spores on hyphae extending from the envelope into the lumen. This interfungal relationship expands our knowledge of the numerous levels of fungal associations and interactions that existed in the Rhynie ecosystem $~ 410$ Ma ago, and thus represents an important component necessary to understand the roles that microbial life played in early continental ecosystems.

\section{Geological setting}

The Rhynie chert locality is situated northwest of the village of Rhynie in Aberdeenshire, Scotland. The fossil-bearing layers occur in the Windyfield Shales Member, within the lower part of the Dryden Flags Formation (Parry et al., 2011). The Lagerstätte is made up of fossiliferous beds containing lacustrine shales and cherts that have been interpreted as a series of ephemeral freshwater pools within a hot spring environment (Rice et al., 2002; Rice and Ashcroft, 2003). Preserved in the cherts are both aquatic (freshwater) facies from the pools and subaerial soil/litter horizons with in situ plants from the margins of the pools. Preservation of the biota is interpreted as being a result of temporary flooding of silica-rich water, or by groundwater high in silica percolating to the surface (Powell et al., 2000).

The Rhynie chert has been regarded as Early (but not earliest) Pragian to earliest Emsian in age based on spore assemblages (Wellman, 2006; Wellman et al., 2006). A more recent high-precision $\mathrm{U}-\mathrm{Pb}$ age estimate indicates an absolute age of $411.5 \pm 1.3 \mathrm{Ma}$ (Parry et al., 2011), while another age constraint using 40Ar/39Ar yields a mean age (recalculated to be U-Pb comparable) of the fossilized biota of $407.1 \pm 2.2 \mathrm{Ma}$ (Mark et al., 2011). According to the latest International Chronostratigraphic Chart (www.stratigraphy.org), an absolute age of $411.5 \pm 1.3 \mathrm{Ma}$ would correspond to the Lochkovian-Pragian boundary (410.8 $\pm 2.8 \mathrm{Ma})$, while the age suggested by Mark et al. (2011) would correspond to the Pragian-Emsian boundary $(407.6 \pm 2.6 \mathrm{Ma})$.

\section{Material and methods}


The fossils considered in this study (Figs. 1-3) were found in thin sections of Rhynie chert that were prepared from four different blocks according to standard procedures outlined in Hass and Rowe (1999). Slides are deposited in the Bayerische Staatssammlung für Paläontologie und Geologie (SNSB-BSPG) at Munich, Germany, under accession numbers SNSB-BSPG 1964 XX 95, SNSB-BSPG 1965 I 319, SNSB-BSPG 2013 V 27 and 77, and SNSB-BSPG 2013 XV 37, 156, and 157. For elucidation and comparison, several images of extant glomeromycotan fungi from the holdings of one of us (C.W.), now deposited at the Herbarium of the Royal Botanic Garden Edinburgh (Herb E), have been provided in Figs. 4 and 5.

\section{Description}

\subsection{Host spores}

The spores that contain the sporocarps occur singly within the cortex of (largely) degraded land plant axes (Figs. 1(1, 7), 2(1), 3(1)), probably of Horneophyton lignieri (Kidston et W.H. Lang) Barghoorn et Darrah and Rhynia gwynne-vaughanii Kidston et W.H. Lang; one specimen occurs in a partially degraded land plant sporangium (Fig. 2(4)). The host spores are spheroidal, $430-560 \mu \mathrm{m}$ in diameter, and appear to have been relatively thickwalled in vivo. However, all host spores have undergone some level of physical and/or biological degradation. The spore wall is highly degraded and disassociated, or even completely missing (Fig. 2(4)); it is mostly replaced with a distinctive layer (HSW in Figs. $1(4), 2(2,3))$ that appears white in thin sections in transmitted light, and may be unstructured or display a faint reticulation (Fig. 2(2,3)). On the other hand, the outer spore wall component of certain extant Glomeromycota can expand considerably in acidic mounting media such as PVLG (Polyvinyl alcohol-lactic acid-glycerol) and, as a result, becomes very difficult to see (Fig. 4). It is therefore also possible that the condition of the fossil host spores is a preservation artifact resulting from the expansion of the wall or a wall component during fossilization. In some host spores there is evidence of a prominent funnel-shaped neck region and subtending hypha (Fig. 1(7,8)); a septum separating the neck from the subtending hypha proper is recognizable in one of the specimens (arrow in Fig. 1(8)).

\subsection{Sporocarps}

The glomeromycotan host spores contain a single, spherical sporocarp that fills the entire spore lumen (Figs. 1(1,7), 2(1), 3(1)) and may even extend into the neck region (Fig. $1(7,8)$ ); evidence of how the fungus that formed the sporocarps entered the host spore is not 
recognizable. Sporocarps of this type have not been found in other types of glomeromycotan spores or elsewhere in the Rhynie chert. Sporocarps are 360-490 $\mu \mathrm{m}$ in diameter. Specimens usually contain large numbers of small spores that do not appear to be organized in any particular order. One specimen contains only a few spores (Fig. 2(4)). The number of spores produced in a sporocarp probably was as large as several hundred, although the exact number can only be estimated since these spores are only viewed in a single section. Spores may be more or less evenly distributed within the sporocarp (Fig. 1(1,7)), or they are sparse to absent in the sporocarp centre (Figs. 2(1), 3(1)); they may be tightly packed (Fig. 1(7)) or relatively loosely organized (Fig. 1(1)).

All sporocarps are bounded by what appears to be a hyphal peridium that perfectly lines the inner side of what formerly was the host spore wall (HE in Fig. 1(3, 4)). It is possible, however, that this structure results from the expanding glebal mycelium becoming constrained by the host spore wall, rather than representing an evidently differentiated hyphal peridium with further differentiated glebal hyphae. We therefore use the terms "peridium-like hyphal envelope", or simply "(hyphal) envelope", rather than "peridium” for this structure. The shape and construction of the envelope is best recognizable in the specimen illustrated in Fig. 2(4), which basically represents an empty envelope, with the majority of spores released from the sporocarp and little left of the host spore and its subtending hypha. Perhaps the most interesting aspect of this specimen is that it demonstrates how the envelope continues into the neck region of the host spore (arrow in Fig. 2(4)). The second specimen showing this condition (Fig. 1(7,8)) also demonstrates that spores even are formed in the envelope extension into the host spore neck.

The envelope is $8-15 \mu \mathrm{m}$ thick and composed of several layers of tightly interlacing and interlocking hyphae that repeatedly branch at wide angles $\left(50-90^{\circ}\right)$, resulting in a characteristic, coralloid pattern (Figs. 2(5-9), 3(9,10)). Envelope hyphae are (2-)2.5-5.5(8) $\mu \mathrm{m}$ wide, more or less tubular or with numerous shallow, irregular constrictions (Fig. 2(7, 8)); they possess what appear to be irregularly distributed septa (arrows in Fig. 3(9, 10)). Branch hyphae may extend around the circumference of the structure, and thus add to the envelope, or extend inwardly to give rise to spores (Fig. 1(10) [arrows], Fig. 3(2-4)). Branches that produce the spores are on average slightly narrower $(\sim 3-5 \mu \mathrm{m}$ wide) than the envelope hyphae, unbranched or branched, and in some specimens fill the sporocarp lumen with a gleba-like meshwork (Fig. 1(3,4)). In other specimens, however, a confluent gleba-like meshwork is not recognizable (Fig. 3(1)). 
Individual spores within the sporocarp range from $(<15-) 16-30(-35) \mu \mathrm{m}$ in diameter; most are spheroidal to ovoid (Figs. 1(2-4), 3(5)) in shape, but pear- and urn-shaped forms [25$35(-50) \times 15-25(->30)]$ occur as well (Figs. $2(4,10), 3(3))$. Some spores are tapered where they are attached to their parental hypha and distally truncated (Fig. 1(4-6)). What appears to be a septum occurs in the parental hypha slightly below the point of attachment to the spore (arrows in Fig. 1(5, 6) and Fig. 3(3)). In other spores that co-occur with the ones described earlier the hyphal attachment is inflated to form a structure morphologically similar to an apophysis or bulbous base (Fig. 3(4, 5, 7) [arrows]), with what appear to be simple septa present between the inflation and spore (arrow in Fig. 3(4)), as well as at the base of the inflation (arrow in Fig. 3(5)). Still other spores possess a distinct, elongate neck that is thicker-walled than the subtending hypha (Figs. 2(10), 3(5) [center of image]). Most spores appear to be mature or near-mature. They possess walls that in the thin sections appear brown in transmitted light and lack any observable ornament, although the walls in some specimens show some folding (Fig. 1(3)). Many spores contain a single, opaque inclusion (Figs. 1(10), $3(4,5))$. In a few specimens the central region of the spore is nearly filled with opaque, granular appearing material (Fig. 2(10)). We are uncertain whether these inclusions represent the aggregated spore contents or some type of artifact. Scattered between the spores in all specimens occur smaller (5-12 $\mu \mathrm{m}$ in diameter) and distinctly thinner-walled spheroidal structures, which are formed singly (Figs. 1(9) [arrow], 3(6)) or in short chains (Fig. 3(8)) on delicate hyphae.

\section{Discussion}

\subsection{Affinities of the fungi}

\subsubsection{Host}

Several types of large, globose or ovoid fungal spores, most between 100 and $350 \mu \mathrm{m}$ in diameter, are among the most common fungal fossils in the Rhynie chert (Kidston and Lang, 1921b; Krings et al, 2012). They usually occur within (degraded) cortical tissues of land plant axes, but may also be present in the matrix; some are associated with hyphae terminating in thin-walled vesicles and occasionally also with remains of arbuscules. The spores differ from each other in size, wall thickness, organization of the wall layering, as well as in whether or not they possess certain special features such as inflations of the subtending hypha, sporiferous saccules, and germination shields (Dotzler et al., 2006, 2009). All large fungal spores in the Rhynie chert are commonly regarded as asexual spores (i.e., azygospores or chlamydospores; see Gerdemann and Trappe, 1974) produced by members of the 
Glomeromycota, and variously referred to in literature as Palaeomyces Renault, Glomites T.N. Taylor et al., Palaeoglomus D. Redecker et al., and Scutellosporites Dotzler et al. (Strullu-Derrien et al., 2014; Taylor et al., 2015). Structures suggestive of endogonalean (Mucoromycotina) affinities of some of the spore-producers have recently been suggested by Strullu-Derrien et al. (2014). Evidence of gametangial fusion, however, is lacking in these specimens. The spores that serve as hosts in the interfungal association described here have been formally described as Palaeomyces gordonii var. major Kidst. et W.H. Lang (Kidston and Lang, 1921b: p. 868). Palaeomyces gordonii var. major is distinctive because it is by far the largest glomeromycotan spore in the Rhynie chert, exceeding the diameter of the secondlargest spore type, Scutellosporites devonicus Dotzler et al. (2006), by 80 to $>100 \mu \mathrm{m}$.

\subsubsection{Sporocarp producer}

The sporocarp-producing fungus in Palaeomyces gordonii var. major has been informally named "Fungus No. 14" by Kidston and Lang (1921b: p. 863-864). However, these authors attribute to "Fungus No. 14" several delicate mycelia together with what they term "vesicles and resting spores" that are widespread in land plant tissue and in and on fungal spores. "Fungus No. 14" is probably not a single biological species, but rather denotes a cluster of several morphologically similar fungi which may or may not be closely related to each other. It is therefore impossible to determine as to whether the "Fungus No. 14" specimens associated with $P$. gordonii var. major all belong to the same species. Minor differences in spore size and spore wall surface folding between the sporocarps illustrated in Figs. 1(1,7), 2(1), and 3(1) may suggest that more than one fungus formed sporocarps within P. gordonii var. major. It is also possible that the variations in spore size are the result of differences in packing density, and that the surface folds are a preservation artifact resulting from shrinkage of the spores prior to or during fossilization. Since we cannot determine whether the sporocarps actually all belong to the same biological species, we refrained from formally describing and naming the sporocarp-forming fungus detailed in this paper.

Sporocarp structure and spore morphology strongly suggest that the fossil sporocarpproducer is a member of the Glomeromycota. Similar sporocarps are found, in several present-day Glomeraceae species, in the genera Funneliformis C. Walker et A. Schüßler, Glomus Tul. et C. Tul., Redeckera C. Walker et A. Schüßler, and Sclerocystis Berk. et Broome (e.g., Schüßler and Walker, 2010; Oehl et al., 2011; Fig. 5(1)). For example, Glomus radiatum (Thaxt.) Trappe et Gerd. (as G. radiatus [sic.]) produces sporocarps (up to $9 \times 7 \times$ $3 \mathrm{~mm}$ ) containing glomoid spores embedded widely dispersed in a matrix of thin-walled 
hyphae (Gerdemann and Trappe, 1974). The spores of G. radiatum, which are 60-110(-120) × 48-75(-90) $\mu \mathrm{m}$ in size, are described as containing hyphae similar to those in the gleba, the illustrations of which are similar to the Rhynie chert fossils discussed herein (Thaxter, 1922: pl. III, 47; Gerdemann and Trappe, 1974: figs. 20-22). Similarly, Thaxter (1922) illustrated a peridial sporocarpic species which he assigned to Endogone incrassata Thaxt., 2-5 mm in diameter, the spores of which are $66 \times 64-75 \times 85 \mu \mathrm{m}$ in size (pl. I, 17-19) and Endogone multiplex Thaxt. (pl. I, 8-10 [now Youngiomyces multiplex (Thaxt.) Y.J. Yao]) with spores 80$90 \times 60-84 \mu \mathrm{m}$ in groups, $350-700 \mu \mathrm{m}$ in diameter, of 10-50 spores that are " $[\ldots]$ surrounded by an envelope of hyphae [...]". However, these latter groups of spores are formed within a large fruiting body $15 \times 12 \mathrm{~mm}$ in size. It should be noted that the spores of these last two species are zygospores (Gerdemann and Trappe, 1970; Yao et al., 1995), whereas those in the Rhynie chert specimens are typical glomoid chlamydospores. Nevertheless, although no small-spored glomeromycotan fungus is described as forming sporocarps of this size and nature, it is quite conceivable that such organisms might have existed and that they might have produced groups of spores of a size similar to those of E. multiplex. The most common extant species in the Glomeraceae that produces small sporocarps enclosed by a peridium are Funneliformis mosseae (T.H. Nicolson et Gerd.) C. Walker et A. Schüßler and F. coronatum (Giovann.) C. Walker et A. Schüßler, but the spores of these species are very large by comparison to the fossil glomoid spores, each sporocarp rarely containing more than about 9 spores (Nicolson and Gerdemann, 1968; Giovannetti et al., 1991; Schüßler and Walker, 2010).

\subsection{Sporocarp morphology and development}

Kidston and Lang (1921b) emphasize that a special relationship appears to exist between "Fungus No. 14" and Palaeomyces gordonii var. major. These authors indicate that hyphae and spores of "Fungus No. 14" may fill the entire lumen of P. gordonii var. major, including the neck region, and in this way assume a "definite and peculiar shape" (op. cit.: p. 863) that conforms to the shape of the host spore. Moreover, this shape remains intact during disintegration of the host spore. The specimens we describe here suggest that the primary reason for this durability is the presence of a coherent, peridium-like envelope constructed of several layers of interlocking multi-branched hyphae (Figs. 2(6-9), 3(9, 10)) that perfectly lines the inner surface of the host spore wall (HE in Fig. 1(3,4)). The term "sporocarp" is used rather loosely in relation to glomeromycotan fungi, and may be used either in a welldefined manner in which the structures containing spores are enclosed in an evidently 
differentiated hyphal peridium with further differentiated glebal hyphae, or merely to describe a dense, undifferentiated cluster of spores (e.g., Schenck and Perez, 1990; Goto and Maia, 2005). Since we cannot determine whether the hyphal envelope in the fossils described here represents a peridium sensu stricto, we use the term "sporocarp" in the broadest sense for these fossils.

All bona fide specimens of this association figured by Kidston and Lang (1921b: pl. V, figs. 48-51), as well as the fossils described in this paper (with the exception of Fig. 2(4)), represent fully developed, (near-)mature sporocarps. As a result, there are no specimens that might provide evidence of a developmental sequence for these structures. Some of the sporocarps are completely filled with small spores (Fig. 1(1, 7); Kidston and Lang, 1921b: pl. $\mathrm{V}$, figs. 48, 50), whereas in others the spores are unevenly arranged, i.e., densely spaced in the outer region and few or absent in the center (Figs. 2(1), 3(1); Kidston and Lang, 1921b: pl. V, fig. 55). This difference might reflect a developmental pattern in which spores developed asynchronously, although perhaps it might also show that some sporocarps aborted in a premature developmental stage. Spores produced earlier in sporocarp development were perhaps borne on shorter parental hyphae (Fig. 3(2, 3)), and thus became situated in the outer region of the mature sporocarp. As the sporocarps matured and new spores were continually produced, the parental hyphae became successively longer and the spores formed more centrally in the sporocarp (Fig. 1(10)). What appears as a confluent, gleba-like meshwork of hyphae embedding the spores in some of the specimens (Fig. 1(3,4)) would accordingly represent the entirety of the parental hyphae of the spores. It is also possible, however, that the central void seen in some of the sporocarps is the result of part of the spores having been dispersed or even consumed by some other organism (see below).

Another interesting aspect concerns the small structures that occur interspersed with the normal-sized spores (Figs. 1(9), 3(6,8)). One interpretation is that these represent immature spores, suggesting that new spores were continuously formed even in fully developed and mature sporocarps. Alternatively, these structures might represent spores that have ceased their growth at some point or were aborted. A third hypothesis, although highly speculative, is that the small structures do not belong to the sporocarp-forming fungus, but rather were produced by yet another fungus that invaded the sporocarps to produce reproductive structures. Sporocarps consisting of two or more species have been observed in several extant fungi, including Glomeromycota (Gerdemann, 1965). Perhaps adding some support to the third hypothesis is the fact that formation of spores in chains has not been observed in any of the extant Glomeromycota. 


\subsection{Paleoecology}

The invasion of glomeromycotan spores by various types of other fungi is a relatively common phenomenon in modern ecosystems (e.g., Taber, 1982a; Sylvia and Schenck, 1983; Boyetchko and Tewari, 1991; Lee and Koske, 1994; Hijri et al., 2002; Purin and Rillig, 2008), and the contents of the host spores (i.e., the intrusive fungus) are highly variable. For example, Daniels and Menge (1980) report large, sausage-shaped hyphae in Glomus spores, while in similar spores Boyetchko and Trewari (1991) describe what are interpreted as thickwalled cysts in the spore lumen. Some of these reports also document the infection canal that penetrates the host spore wall (e.g., Petitberghien, 1956). However, we are not aware of any examples of extant intrusive fungi associated with glomeromycotan spores that include the complement of features described in these Rhynie chert fossils. The only other sporocarpforming fungus described to date from the Rhynie chert is Glomites sporocarpoides Karatygin et al. (2006). This taxon occurs in axes of the land plants Aglaophyton major (Kidston et W.H. Lang) D.S. Edwards and Rhynia gwynne-vaughanii; it produces sporocarps that contain glomoid spores.

In the fossils described here there appears to be some correlation between the degree of sporocarp development and the organization of the host spore wall. Evidence of sporocarps has not been found in intact glomeromycotan spores showing little or no evidence of wall degradation, with one possible exception (Kidston and Lang, 1921b: pl. V, figs. 55, 56). However, this specimen does not contain a peridium or peridium-like hyphal envelope but only spores, and thus may represent a different association. All spores contained in sporocarps bounded by a hyphal envelope lack the actual host spore wall. The position of the host spore wall is identified by either wall remnants (e.g., in the neck region; Fig. $1(7,8)$ ) or a white residual layer or space where the wall once was located (Figs. 1(1, 2), 2(1-3)), or a combination of both conditions (e.g., Kidston and Lang, 1921b: pl. V, fig. 50). Two competing hypotheses might be offered to explain the relationship of Palaeomyces gordonii var. major spores and the intrusive, sporocarp-producing fungus.

The first hypothesis suggests that viable spores were invaded by a mycoparasite. Interpreting the sporocarp producer as a mycoparasite appears reasonable, as glomeromycotan spores, which are among the largest spores known in the fungal kingdom [e.g., $>800 \mu \mathrm{m}$ in diameter in Gigaspora gigantea (T.H. Nicolson et Gerd.) Gerd. et Trappe; Nicolson and Gerdemann, 1968], certainly represented a suitable host for parasitic microfungi because they contain abundant and easily accessible nutrients (Bonfante et al., 1994). As the parasite 
develops in the lumen of the host, an increasing percentage of the host spore, including its wall, is used in the formation of the parasite sporocarp. This results in the host spore wall being represented only by a void or residual layer that surrounds the parasite sporocarp. Evidence to support this hypothesis could be the identification of a host response in the host spore wall. Many other Rhynie chert glomeromycotan spores display host responses to parasite attacks in the form of prominent papillae or callosities (Hass et al., 1994). However, it is also probable that some of the host fungi had no observable host response. Moreover, even if there was some indication of a host response in the spore wall, such evidence was likely lost during sporocarp development; for the same reason, we have not found any evidence of the penetration site.

If the sporocarp producer was a biotrophic endoparasite, infection probably occurred very early in the development of the host spore, with the infection site not visible on developed hosts. In this scenario, the endoparasite could have benefited from the fact that a network of living host mycelium was actively degrading the plant substrate, feeding the endoparasite within the developing host. Moreover, the endoparasite may have suppressed the maturation of the host spore in order to maximize its supply of nutrients and prolong the flow of nutrients into the immature host. Suppression of maturation could also explain the absence of well-defined walls on the infected spores. There are several examples of extant endoparasitic fungi that control the development of their host fruiting structures. For example, the ascomycete Epichloë amarillans J.F. White suppresses the development of grass inflorescences and forms a stroma on the inflorescence primordium which never fully develops (White, 1993, 1994; White et al., 1997). The fungus prevents the host from developing a cuticle in order to continue the flow of water and nutrients into the stroma.

The second hypothesis suggests that the sporocarp-producing fungus colonized nonviable spores or spores that had already germinated. In this scenario, the host spore simply represents a convenient site for sporocarp development, the absence of the host spore wall in the specimens being a preservation artifact or the result of natural degradation. Support for this hypothesis is seen in uninfected glomeromycotan spores in which the wall is (partially) replaced with a white residual layer that also occur in the Rhynie chert (e.g., Kidston and Lang, 1921b: pl. I, figs. 6, 7, 10). If this hypothesis is accurate, then the absence of host responses would be the normal condition. However, this raises the question why "Fungus No. 14" produced sporocarps inside glomeromycotan spores rather than on or in the substrate? It is possible that the host spores in some way positively affected sporulation or spore development in this fossil, perhaps as a result of confined space and certain nutrients. For 
example, observations by one of us (C.W.) suggest that the presence of a surface (e.g., the wall of a large spore) stimulates sporulation in certain Glomeromycota. Moreover, there is some evidence among extant Glomus species sporulating inside glomeromycotan spores (Fig. $5(3,4)$ ) and other enclosures (Fig. 5(2)) to suggest these confined spaces may also provide protection from degradative agents (Rabatin and Rhodes, 1982; Taber, 1982b; St. John et al., 1983; Koske, 1984). For example, it has been suggested that the relative value of fungal spores in the diet of certain collembolans varied with the capability of these animals to rupture spores (Nakamori and Suzuki, 2005). In this context development of a sporocarp within glomeromycotan spores may have reduced susceptibility of the immature spores to certain mycophagous arthropods which existed in the Rhynie paleoecosystem (Habgood et al., 2003).

\section{Conclusions}

The Early Devonian Rhynie chert continues to provide information that figures prominently in our understanding of the diversity and roles of fungi in early continental ecosystems (Taylor et al., 2015). Most important is perhaps the discovery of various types of associations and interactions between fungi and other organisms in the Rhynie paleoecosystem, including endomycorrhizas formed by Glomeromycota and possibly members of the Mucoromycotina with several of the Rhynie chert land plants (Remy et al., 1994; Taylor et al., 2003, 2005; Strullu-Derrien et al., 2014). Moreover, Rhynie chert fossils of glomeromycotan spores have demonstrated that this lineage of fungi was morphologically diverse by the Early Devonian, and have pushed back the evolutionary origin of the main spore types in the Glomeromycota (i.e., glomoid, gigasporoid, and acaulosporoid) to a time before the evolution of true roots (Dotzler et al., 2009). Another interesting aspect concerning glomeromycotan spores in the Rhynie chert is their function as a habitat and carbon source for other fungi. These interfungal relationships, some of which were initially reported by Kidston and Lang (1921b), are currently receiving renewed interest, and it is becoming increasingly evident that microfungi associated with glomeromycotan spores were abundant and diverse in the Rhynie paleoecosystem (Taylor et al., 1992; Hass et al., 1994; Krings et al., 2009, 2010; Krings and Taylor, 2014), perhaps even paralleling the diversity of these organisms today (e.g., Purin and Rillig, 2008). Unfortunately, the nutritional modes of most spore-colonizing fungi in the Rhynie chert cannot currently be assessed, and thus the impacts of these organisms on early continental ecosystem dynamics remain largely unknown.

Glomeromycotan spores from the Rhynie chert represent an important avenue of research that 
requires careful screening, not only for characters useful in assessing glomeromycotan diversity in this paleoecosystem, but also for information on additional interfungal relationships. This focus will also assist in determining whether the fungi residing and/or reproducing on or within other fungal spores were generalists colonizing all available spores or some type of host-specific specialist.

\section{Acknowledgments}

We acknowledge financial support from the Deutsche Forschungsgemeinschaft (DFG grant Ke 584/13-2 to H.K. and M.K.) and the National Science Foundation (EAR-0949947 to T.N.T. and M.K.). Nora Dotzler, Helmut Martin, and Stefan Sónyi (all Munich, Germany) are acknowledged for technical assistance. We appreciate the insightful comments and suggestions of two reviewers.

\section{References}

Bonfante, P., Balestrini, R., Mendgen, K., 1994. Storage and secretion processes in the spore of Gigaspora margarita Becker \& Hall as revealed by high-pressure freezing and freeze substitution. New Phytologist 128, 93-101.

Boyetchko, S.M., Tewari, J.P., 1991. Parasitism of spores of the vesicular-arbuscular mycorrhizal fungus, Glomus dimorphicum. Phytoprotection 72, 27-32.

Daniels, B.A., Menge, J.A., 1980. Hyperparasitization of vesicular-arbuscular mycorrhizal fungi. Phytopathology 70, 584-588.

Dotzler, N., Krings, M., Taylor, T.N., Agerer, R., 2006. Germination shields in Scutellospora (Glomeromycota: Diversisporales, Gigasporaceae) from the 400 million-year-old Rhynie chert. Mycological Progress 5, 178-184.

Dotzler, N., Walker, C., Krings, M., Hass, H., Kerp, H., Taylor, T.N., Agerer, R., 2009. Acaulosporoid glomeromycotan spores with a germination shield from the 400-millionyear-old Rhynie chert. Mycological Progress 8, 9-18.

Gerdemann, J.W., 1965. Vesicular-arbuscular mycorrhizae formed on maize and tuliptree by Endogone fasciculata. Mycologia 57, 562-575.

Gerdemann, J.W., Trappe, J.M., 1970. Endogone incrassata: A zygosporic species with hollow sporocarps. Mycologia 62, 1204-1208.

Gerdemann, J.W., Trappe, J.M., 1974. The Endogonaceae of the Pacific Northwest. Mycological Memoirs 5, 1-76. 
Giovannetti, M., Avio, L., Salutina, L., 1991 Morphological, cytochemical, and ontogenetic characteristics of a new species of vesicular-arbuscular mycorrhizal fungus. Canadian Journal of Botany 69, 161-167.

Goto, B.T., Maia, L.C., 2005. Sporocarpic species of arbuscular mycorrhizal fungi

(Glomeromycota), with a new report from Brazil. Acta Botanica Brasilica 19, 633-637.

Habgood, K.S., Hass, H., Kerp, H., 2003. Evidence for an early terrestrial food web:

coprolites from the Early Devonian Rhynie chert. Transactions of the Royal Society Edinburgh, Earth Sciences 94, 371-389.

Hass, H., Rowe, N.P., 1999. Thin sections and wafering, in: Jones, T.P., Rowe, N.P. (Eds.), Fossil plants and spores: modern techniques. Gological Society, London, pp. 76-81.

Hass, H., Taylor, T.N., Remy, W., 1994. Fungi from the Lower Devonian Rhynie chert: mycoparasitism. American Journal of Botany 81, 29-37.

Hijri, M., Redecker, D., MacDonald-Comber Petetot, J.A., Voigt, K., Wöstemeyer, J., Sanders, I.R., 2002. Identification and isolation of two ascomycete fungi from spores of the arbuscular mycorrhizal fungus Scutellospora castanea. Applied and Environmental Microbiology 68, 4567-4573.

Karatygin, I.V., Snigirevskaya, N.S., Demchenko, K.N., 2006. Species of the genus Glomites as plant mycobionts in Early Devonian ecosystems. Paleontological Journal 40, 572 579.

Kidston, R., Lang, W.H., 1917. On Old Red Sandstone plants showing structure, from the Rhynie Chert Bed, Aberdeenshire. Part I. Rhynia Gwynne-Vaughani, Kidston and Lang. Transactions of the Royal Society Edinburgh 51, 761-784.

Kidston, R., Lang, W.H., 1920a. On Old Red Sandstone plants showing structure, from the Rhynie Chert Bed, Aberdeenshire. Part II. Additional notes on Rhynia GwynneVaughani, Kidston and Lang; with descriptions of Rhynia major, n.sp., and Hornea lignieri, n.g. n.sp. Transactions of the Royal Society Edinburgh 52, 603-627.

Kidston, R., Lang, W.H., 1920b. On Old Red Sandstone plants showing structure, from the Rhynie Chert Bed, Aberdeenshire. Part III. Asteroxylon Mackiei, Kidston and Lang. Transactions of the Royal Society Edinburgh 52, 643-680.

Kidston, R., Lang, W.H., 1921a. On Old Red Sandstone plants showing structure, from the Rhynie Chert Bed, Aberdeenshire. Part IV. Restorations of the vascular cryptogams, and discussion of their bearing on the general morphology of the Pteridophyta and the origin of the organisation of land-plants. Transactions of the Royal Society Edinburgh $52,831-854$. 
Kidston, R., Lang, W.H., 1921b. On Old Red Sandstone plants showing structure, from the Rhynie Chert Bed, Aberdeenshire. Part V. The Thallophyta occurring in the peat-bed; the succession of the plants throughout a vertical section of the bed, and the conditions of accumulation and preservation of the deposit. Transactions of the Royal Society Edinburgh 52, 855-902.

Koske, R.E., 1984. Spores of VAM fungi inside spores of VAM fungi. Mycologia 76, 853862.

Krings, M., Taylor, T.N., 2014. An unusual fossil microfungus with suggested affinities to the Chytridiomycota from the Lower Devonian Rhynie chert. Nova Hedwigia 99, 403-412. Krings, M., Dotzler, N., Taylor, T.N., 2009. Globicultrix nugax nov. gen. et nov. spec. (Chytridiomycota), an intrusive microfungus in fungal spores from the Rhynie chert. Zitteliana A 48/49, 165-170.

Krings, M., Dotzler, N., Longcore, J.E., Taylor, T.N., 2010. An unusual microfungus in a fungal spore from the Lower Devonian Rhynie chert. Palaeontology 53, 753-759.

Krings, M., Taylor, T.N., Dotzler, N., 2012. Fungal endophytes as a driving force in land plant evolution: evidence from the fossil record, in: Southworth, D. (Ed.), Biocomplexity of plant-fungal interactions. John Wiley \& Sons, Inc., Ames, IA, pp. 527.

Lee, P.J., Koske, R.E., 1994. Gigaspora gigantea: parasitism of spores by fungi and actinomycetes. Mycological Research 98, 458-466.

Mark, D.F., Rice, C.M., Fallick, A.E., Trewin, N.H., Lee, M.R., Boyce, A., Lee, J.K.W., 2011. ${ }^{40} \mathrm{Ar} /{ }^{39} \mathrm{Ar}$ dating of hydrothermal activity, biota and gold mineralization in the Rhynie hot-spring system, Aberdeenshire, Scotland. Geochimica et Cosmochimica Acta $75,555-569$.

Nakamori, T., Suzuki, A., 2005. Spore-breaking capabilities of collembolans and their feeding habitat within sporocarps. Pedobiologia 49, 261-267.

Nicolson T.H., Gerdemann , J.W., 1968. Mycorrhizal Endogone species. Mycologia 60, 313325.

Oehl, F., Alves da Silva, G., Goto, B.T., Sieverding, E., 2011. Glomeromycota: three new genera and glomoid species reorganized. Mycotaxon 116, 75-120.

Parry, S.F., Noble, S.R., Crowley, Q.G., Wellman, C.H., 2011. A high precision U-Pb age constraint on the Rhynie chert Konservat-Lagerstätte: time scale and other implications. Journal of the Geological Society London 168, 863-872. 
Petitberghien, P., 1956. Les champignons hypogés de la région de Dijon. Bulletin scientifique de Bourgogne 16, 115-155.

Powell, C.L., Trewin, N.H., Edwards, D., 2000. Palaeoecology and plant succession in a borehole through the Rhynie cherts, Lower Old Red Sandstone, Scotland, in: Friend, P.F., Williams, B.P.J. (Eds.), New perspectives on the Old Red Sandstone. Geological Society of London Special Publication 180, 439-457.

Purin, S., Rillig, M.C., 2008. Parasitism of arbuscular mycorrhizal fungi: reviewing the evidence. FEMS Microbiology Letters 279, 8-14.

Rabatin, S.C., Rhodes, L.H., 1982. Acaulospora bireticulata inside orbatid mites. Mycologia $74,859-861$.

Remy, W., Taylor, T.N., Hass, H., Kerp, H., 1994. Four hundred-million-year-old vesicular arbuscular mycorrhizae. Proceedings of the National Academy of Sciences USA 91, 11841-11843.

Rice, C.A., Ashcroft, W.A., 2003. The geology of the northern half of the Rhynie basin, Aberdeenshire, Scotland. Transactions of the Royal Society Edinburgh, Earth Sciences 94, 299-308.

Rice, C.M., Trewin, N.H., Anderson, L.I., 2002. Geological setting of the Early Devonian Rhynie cherts, Aberdeenshire, Scotland: An early terrestrial hot spring system. Journal of the Geological Society London 159, 203-214.

Schenck, N.C., Perez, Y., 1990. Manual for the identification of VA mycorrhizal fungi. Synergistic Publications, Gainesville, FL.

Schüßler, A., Walker, C., 2010. The Glomeromycota. A Species List with New Families and New Genera. Published in libraries at The Royal Botanic Garden Edinburgh, The Royal Botanic Garden Kew, Botanische Staatssammlung Munich, and Oregon State University. [available online at www.amf-phylogeny.com; last accessed March 25, 2015]

St. John, T .V., Coleman, D.C., Reid, C.P.P., 1983. Association of vesicular-arbuscular mycorrhizal hyphae with soil organic particles. Ecology 64, 957-959.

Strullu-Derrien, C., Kenrick, P., Pressel, P., Duckett, J.G., Rioult, J.P., Strullu, D.G., 2014. Fungal associations in Horneophyton ligneri from the Rhynie Chert (c. 407 million year old) closely resemble those in extant lower land plants: novel insights into ancestral plant-fungus symbioses. New Phytologist 203, 964-979. 
Sylvia, D.M., Schenck, N.C., 1983. Soil fungicides for controlling chytridiaceous mycoparasites of Gigaspora margarita and Glomus fasciculatum. Applied and Environmental Microbiology 45, 1306-1309.

Taber, R.A., 1982a. Gigaspora spores and associated hyperparasites in weed seeds in soil. Mycologia 74, 1026-1031

Taber, R.A., 1982b. Occurrence of Glomus spores in weed seeds in soil. Mycologia 74, 515520.

Taylor, T.N., Remy, W., Hass, H., 1992. Fungi from the Lower Devonian Rhynie chert: Chytridiomycetes. American Journal of Botany 79, 1233-1241.

Taylor, T.N., Klavins, S.D., Krings, M., Taylor, E.L., Kerp, H., Hass, H., 2003. Fungi from the Rhynie chert: a view from the dark side. Transactions of the Royal Society Edinburgh, Earth Sciences 94, 455-471.

Taylor, T.N., Kerp. H., Hass, H., 2005. Life history biology of early land plants: deciphering the gametophyte phase. Proceedings of the National Academy of Sciences USA 102, $5892-5897$.

Taylor, T.N., Krings, M., Taylor, E.L., 2015. Fossil fungi. Elsevier/Academic Press Inc., Amsterdam, Boston, Heidelberg, London.

Thaxter, R., 1922. A revision of the Endogoneae. Proceedings of the American Academy of Arts and Sciences 57, 291-351.

Wellman, C.H., 2006. Spore assemblages from the Lower Devonian 'Lower Old Red Sandstone' deposits of the Rhynie outlier, Scotland. Transactions of the Royal Society of Edinburgh, Earth Sciences 97, 167-211.

Wellman, C.H., Kerp, H., Hass, H., 2006. Spores of the Rhynie chert plant Aglaophyton (Rhynia) major (Kidston and Lang) D.S. Edwards, 1986. Review of Palaeobotany and Palynology 142, 229-250.

White, J.F., Jr., 1993. Endophyte-host associations in grasses. XIX. A systematic study of some sympatric species of Epichloë in England. Mycologia 85, 444-455.

White, J.F., Jr., 1994. Endophyte-host associations in grasses. XX. Structural and reproductive studies of Epichloë amarillans sp. nov. and comparisons to E. typhina. Mycologia 86, 571-580.

White, J. F., Jr., Bacon, C.W., Hinton, D.M., 1997. Modifications of host cells and tissues by the biotrophic endophyte Epichlö̈ amarillans (Clavicipitaceae; Ascomycotina). Canadian Journal of Botany 75, 1061-1069. 
Yao, Y.J., Pegler, D.N., Young, T.W.K., 1995. Youngiomyces, a new genus in Endogonales (Zygomycotina). Kew Bulletin 50, 349-357. 


\section{Figure captions}

Fig. 1. Sporocarps in Palaeomyces gordonii var. major gomeromycotan spores from the Lower Devonian Rhynie chert. 1. Sporocarp bounded by peridium-like hyphal envelope extending along the inner wall surface of a glomeromycotan spore; white halo around spore represents position of host spore wall; slide SNSB-BSPG 2013 XV 37. 2-6. Details of Fig. 1(1) (some in different focal plane). 2: Loose arrangement of spores in sporocarp (compare with Fig. 1(7)); 3, 4: Hyphal envelope [HE], hyphae extending from envelope into sporocarp lumen, and spores; HSW indicates position of host spore wall (white residual layer); 5, 6: Individual spores borne terminally on hypha; arrows indicate position of putative septum in parental hypha. 7. Sporocarp extending into the neck region of host spore; note dense spacing of spores in comparison to sporocarp shown in Fig. 1(1); slide SNSB-BSPG 2013 XV 157. 810. Details of Fig. 1(7) (some in different focal plane). 8: Neck region and subtending hypha of host spore; arrow indicates position of septum; 9: Several mature and one immature (arrow) spores and small spheroidal structure (arrow); 10: Inner surface of hyphal envelope from which extend tubular hyphae into sporocarp lumen (arrows). Scale bars: $100 \mu \mathrm{m}(1,7)$, $50 \mu \mathrm{m}(2,8), 20 \mu \mathrm{m}(3,4), 10 \mu \mathrm{m}(5,6,9,10)$.

Fig. 2. Sporocarps in Palaeomyces gordonii var. major gomeromycotan spores from the Lower Devonian Rhynie chert. 1. Sporocarp with spores densely spaced in periphery and almost no spores in center; note largely disintegrated host spore wall and neck region (arrow); slide SNSB-BSPG 2013 V 54. 2, 3. Details of Fig. 2(1), showing periphery of sporocarp and white residual layer (HSW) in place of degraded host spore wall; note the faint reticulation in residual layer. 4. Older, nearly empty sporocarp inside partially degraded land plant sporangium; note hyphal envelope extension into neck region of host spore (arrow); slide SNSB-BSPG 2013 V 27. 5-10. Details of Fig. 1(4) (some in different focal plane). 5: Hyphal envelope extending into neck region of host spore; 6-9: Coralloid envelope hyphae; note repeated branching at wide angles (e.g., arrow in Fig. 2(8)); 10: One of the few spores left in sporocarp; note distinct neck region. Scale bars: $100 \mu \mathrm{m}(1,4), 20 \mu \mathrm{m}(2,3), 10 \mu \mathrm{m}(5,6-10)$.

Fig. 3. Sporocarps in Palaeomyces gordonii var. major gomeromycotan spores from the Lower Devonian Rhynie chert. 1. Sporocarp containing spores; note the absence of spores in the center; slide SNSB-BSPG 2013 XV 156. 2-8. Details of Fig. 3(1) (some in different focal plane). 2, 3: Transition from hyphal envelope to spore layer; arrow indicates what appears to 
be septum in hypha; 4: Region of spore layer showing inclusions in some spores and inflated hyphal attachments; arrow indicates septum between spore and inflation of hyphal attachment; 5: Variability in spore attachment: spore in upper left of image glomoid, the one in middle with elongate neck region, and the upper-right one with spindle-shaped inflation of parental hypha; arrow indicates putative septum at base of inflation; 6: Thin-walled spore-like structure with hyphal attachment; 7: Two spores with apophysis-like inflation of hyphal attachment; 8: Spore-like structures arranged in chain. 9, 10. Details of hyphal envelope, showing organization of multi-branched interlocking hyphae; note irregular septation (arrows); slide SNSB-BSPG 2013 V 77. Scale bars: $100 \mu \mathrm{m}$ (1), $10 \mu \mathrm{m}(2-8,10), 20 \mu \mathrm{m}(9)$.

Fig. 4. Chlamydospore of Glomus macrocarpum Tul. et C. Tul., showing expansion of normally thin outermost wall component in acidic mounting medium (PVLG); note that component on expansion (arrows) becomes difficult to see because of its similar refractive index to that of the mounting medium. Scale bar: $10 \mu \mathrm{m}$.

Fig. 5. Extant glomeromycotan fungi showing sporocarpic and pseudosporocarpic behavior. 1. Transverse section through a normal sporocarp of Sclerocystis coremioides Berk. et Broome, showing spores radiating from a sterile central mycelial plexus, all surrounded by a genuine thin peridium. 2. "Sporocarp" formed by production of many spores constrained by what is thought to be a degenerated nodule of Bradyrhizobium sp. 3. Empty chlamydospore of Claroideoglomus sp. occupied by much smaller colorless glomus-like spores, probably of a normally ectocarpic Paraglomus sp. 4. Empty spore of Gigaspora sp. occupied by a cluster of Archaeospora sp., giving the appearance of a sporocarp with spores contained within a rigid wall. Scale bars: $250 \mu \mathrm{m}$ (1), $500 \mu \mathrm{m}$ (2), $20 \mu \mathrm{m}$ (3), $100 \mu \mathrm{m}$ (4). 


\section{1}
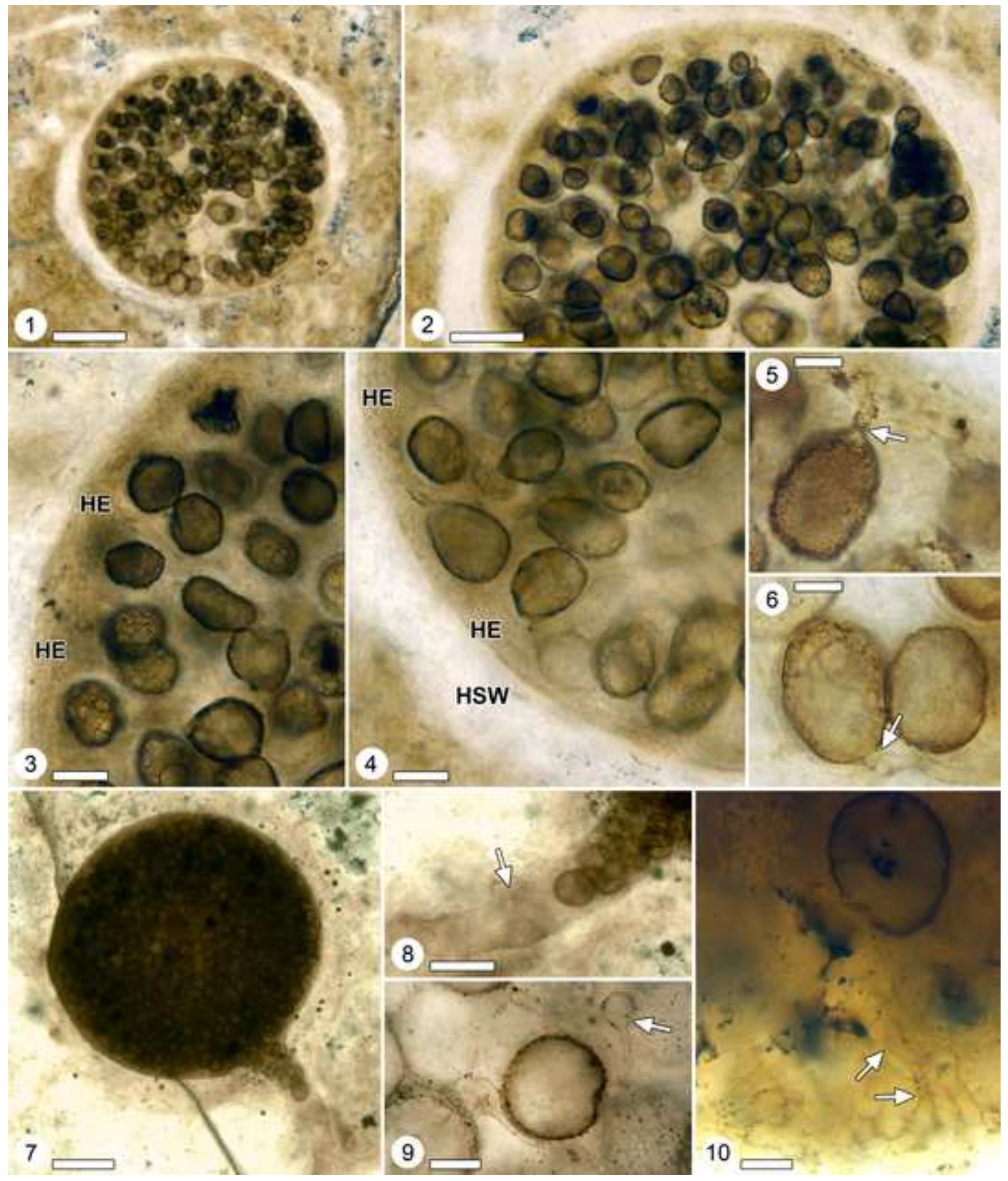

as:

2

4

\section{HSW}
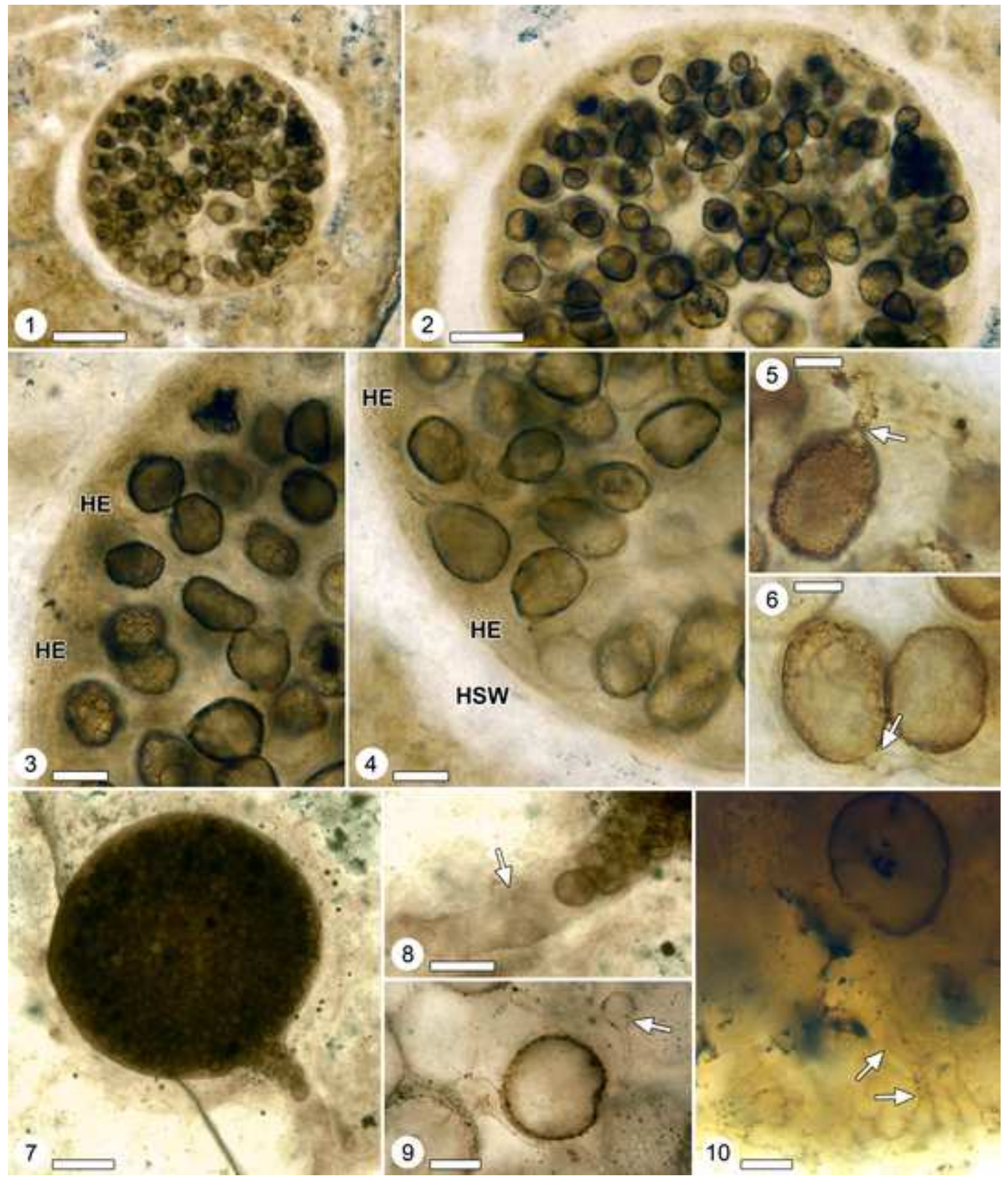

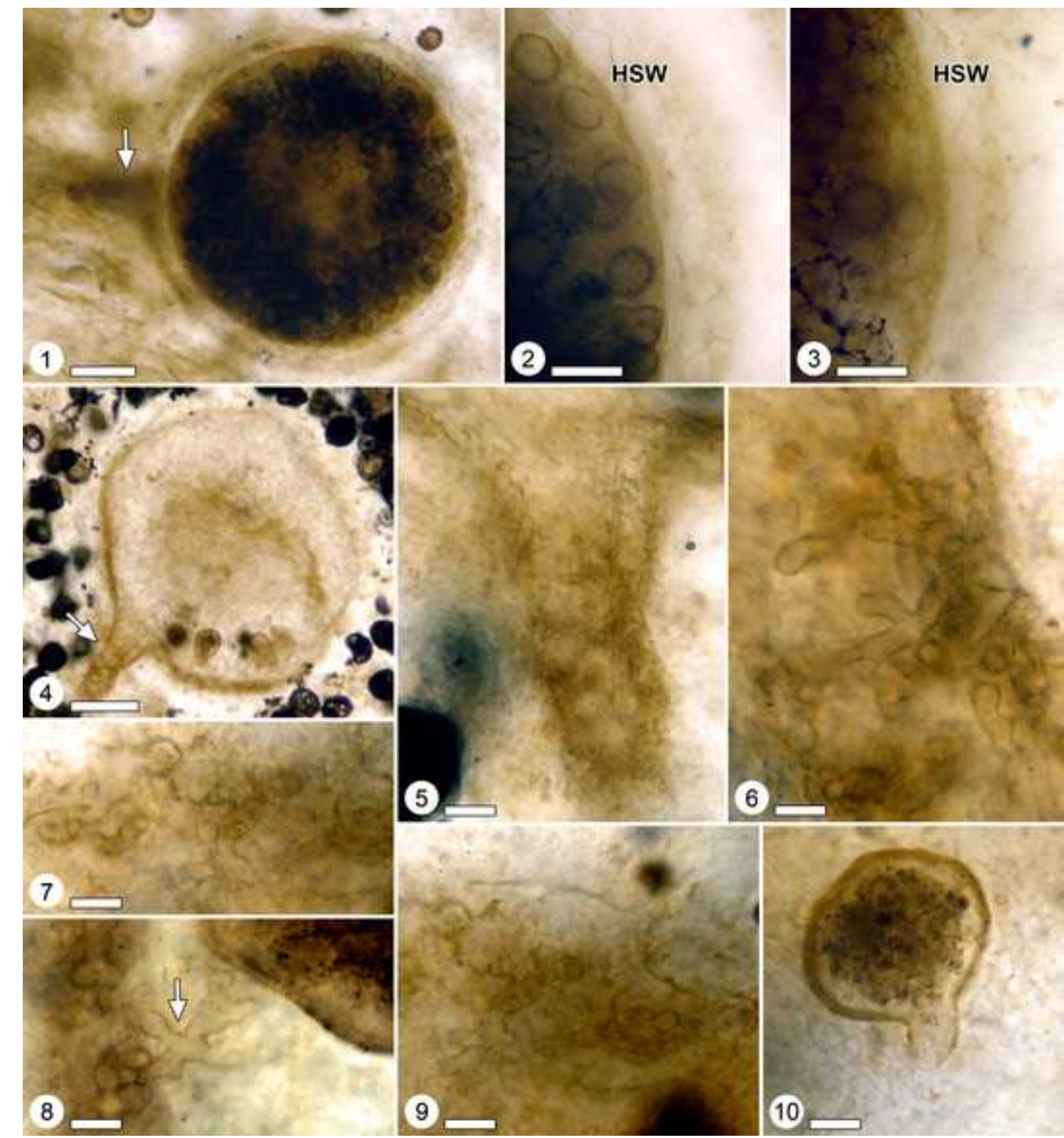

(5)

6

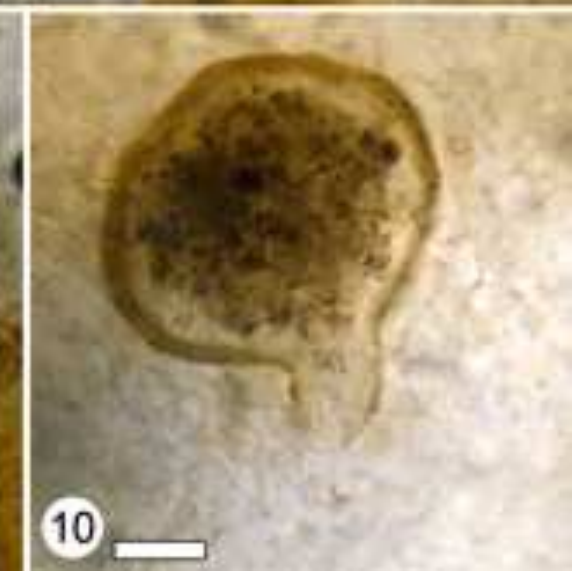



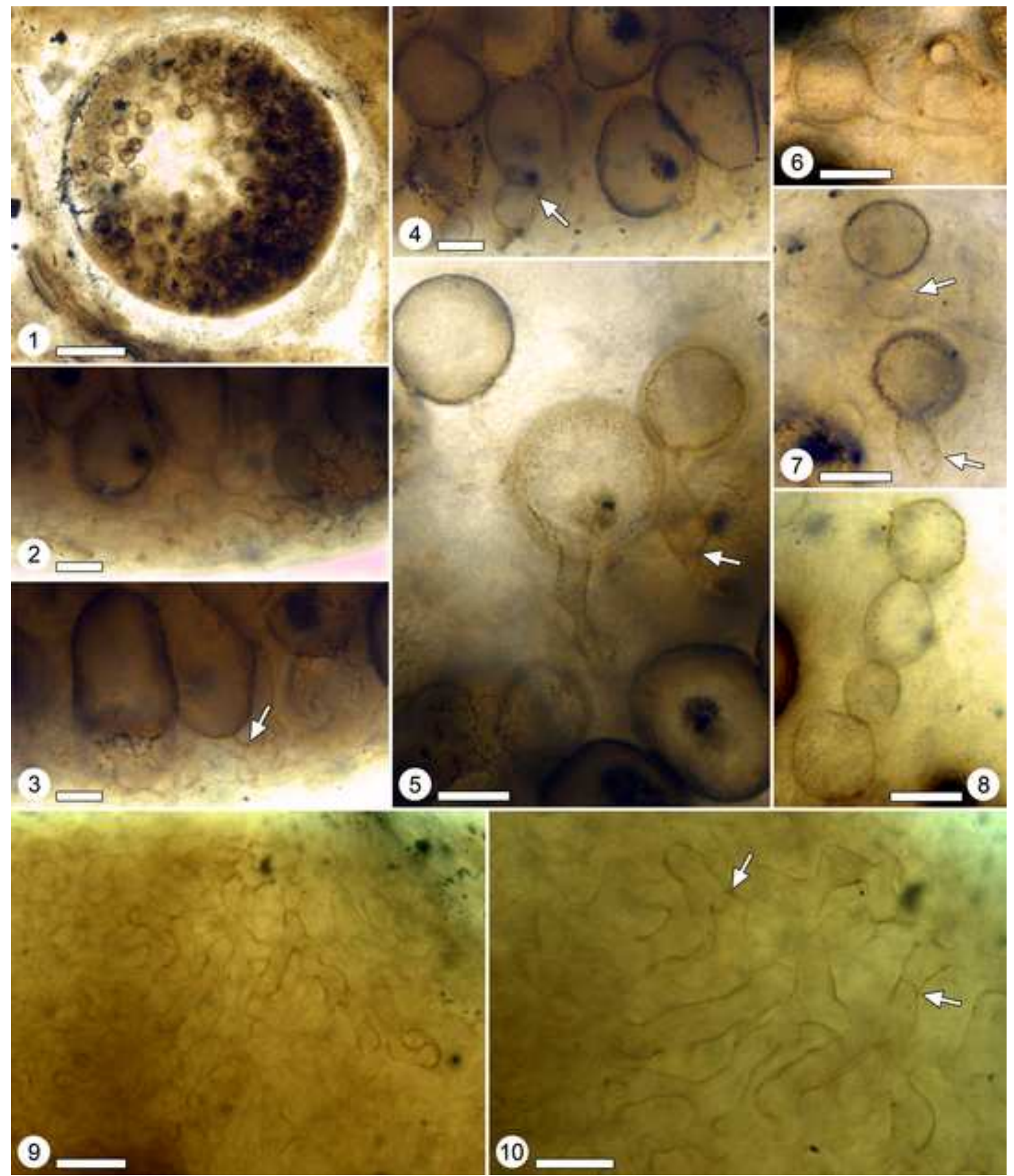

(5)

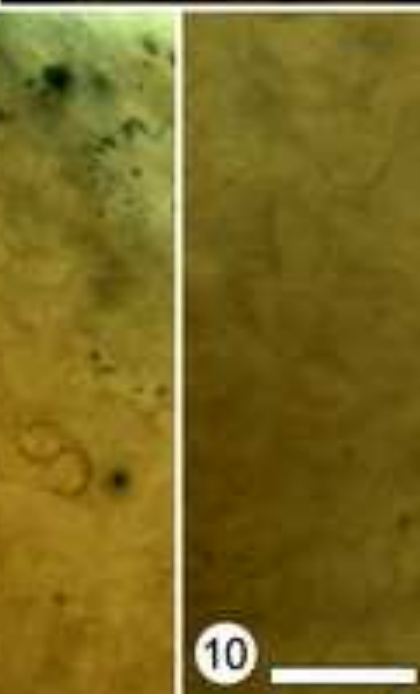

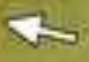

10 
Figure 4

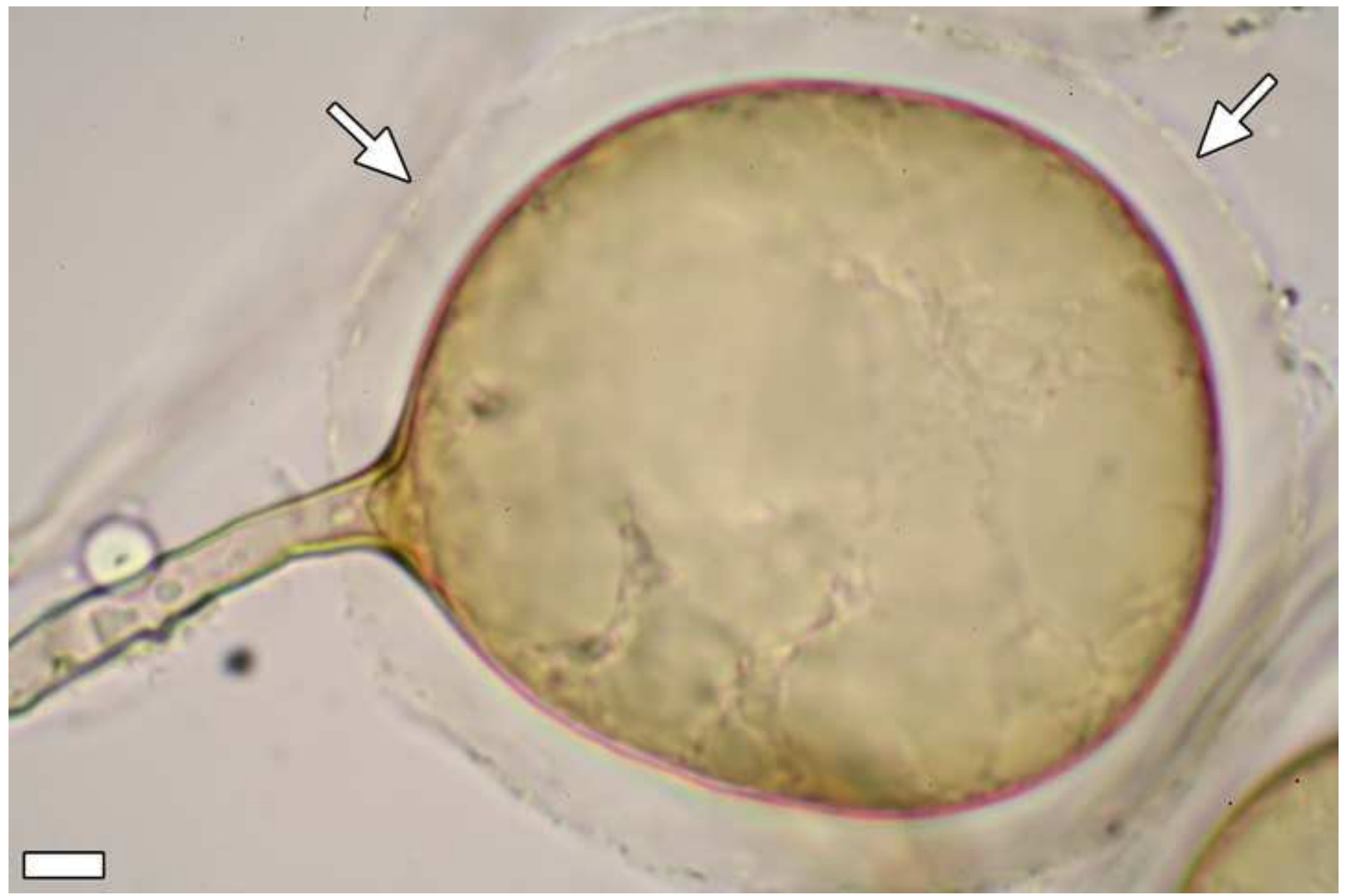



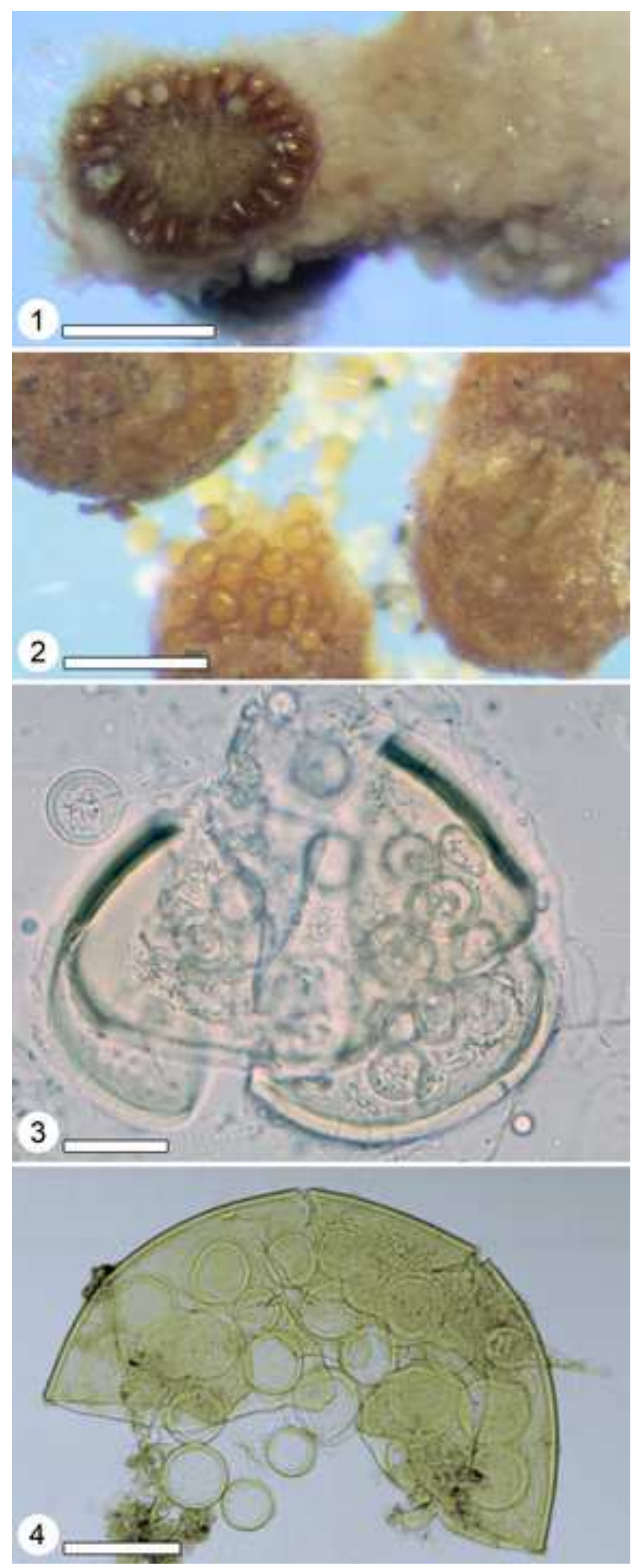

Figure 5

$$
4
$$

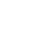

\section{5}

5

\section{Figure}

-

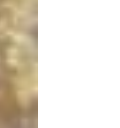

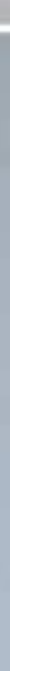

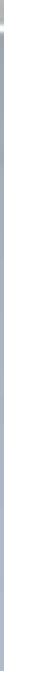

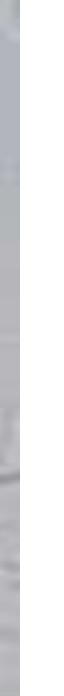
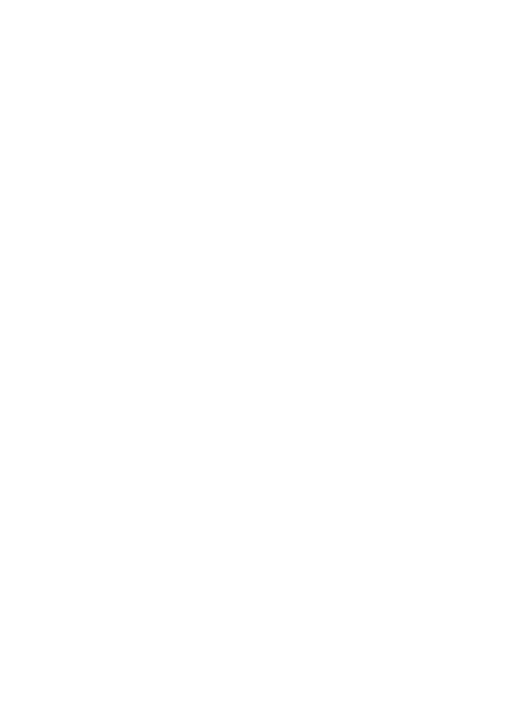